\title{
Profile of Emotional-Social Competence of Quarantine Participants of International Junior Science Olympiad (IJSO)
}

\author{
Nadia Aulia Nadhirah \\ Educational Psychology and Guidance \\ Universitas Pendidikan Indonesia Bandung \\ nadia.aulia.nadhirah@upi.edu
}

\author{
Azni Nurul Fauzia \\ Educational Psychology and Guidance \\ Universitas Pendidikan Indonesia Bandung \\ Azni.fauzia@gmail.com
}

\begin{abstract}
Participants of the International Junior Science Olympiad (IJSO) are required not only to excellent in academics but are expected to have emotional-social competence for the conflict resolution process in the quarantine process. This study aims to describe the emotional-social competence of IJSO participants. The research design used was qualitative with a phenomenological model. The subjects of the study were the 20142018 IJSO participants. Data obtained from observations, interviews and field notes. The results of the study describe the emotional-social competence of IJSO participants who have not been able to express their feelings appropriately and are picky when making friends, especially in group work processes. Therefore, it is important guidance and counseling services provided as a facilitator for the development of characteristics to be superior.
\end{abstract}

Keywords: emotional-social competence, guidance and counseling, science olympiad

\section{INTRODUCTION}

Participants International Junior Science Olympiad (IJSO) are sons and daughters of representatives of Indonesia at the junior high level who have gone through a rigorous selection process at the national level in the fields of Physics, Chemistry, and Biology. Before the IJSO event takes place, IJSO participants must follow the quarantine process for reselection which lasts for 44 days. Quarantine activities are intended to strengthen the ability of participants.

The intensive quarantine program requires participants to follow the learning process for 13 hours in class, the participant's self-development focuses more on developing cognitive abilities compared to the character's development of participants. In the quarantine process, IJSO participants did not escape a conflict. IJSO participants tend to be difficult to express and express feelings of discomfort towards them.

Friends For example, if there are friends who are in the bathroom for a long time, do not maintain cleanliness, or do not want to budge when arguing about the material. This behavior influences their emotional-social competence. Students who are furious because they do not like the behavior of their friends, impact on teamwork, participants tend to be subjective, less open to accept the shortcomings of others, and do not want to budge with their friends.

IJSO participants who are identified as gifted groups, have high intellectual abilities in gifted adolescents are able to make gifted groups present themselves normatively or even superior as psychosocial adjustments compared to non- gifted groups. The level of emotional-social problems faced by gifted learners is not only seen from the individual's perspective of the conditions faced, but also related to the way of the environment around gifted individuals, this is related to the level of individual self- awareness that can trigger data collection which is biased, due to the individual's highly valued competence or ability. Various statements were found conflicting statements. On the one hand gifted students are considered as students who have good emotional abilities and are able to adjust themselves normatively, but on the other hand some studies find that gifted students are considered to be very vulnerable to being confronted with conflicts in their social environment.

Participants who are in their early teens are naturally being faced with physiological changes that place participants in having the need to adjust to many changes towards the maturity process of an adult. Failure of participants to carry out developmental tasks such as adjusting and building self-image during adolescence can have an impact on dissatisfaction, low self- esteem, and feelings of worthlessness, in extreme cases it can trigger adolescents to commit suicide.

In addition, IJSO quarantine participants are faced with pressure, hope, increased intellectual capacity and also psychological needs to fulfill development tasks during adolescence, conditions faced by participants in adolescent groups can face disturbances in the form of both disturbance of thoughts, feelings and behavioral disorders. Stress, sadness, anxiety, loneliness, doubt in adolescents make them take risks by doing delinquency.

Based on the issue of the conditions faced by the participants, the emotional - social competence of the IJSO participants is an important key for participants to be able to face the stressful quarantine process. Daniel Goleman argues that the success of one's life will be more determined by his emotional social abilities than by intellectual abilities. Social emotional abilities become the foundation for individuals to interact with the wider environment. Social emotional abilities are also included in the ability to control themselves well. The inability of individuals to control themselves can cause various social emotional problems with others, so that it can place individuals in difficulties and obstacles in the 
development process. The quarantine process as a social system is a place that should be conducive to supporting the learning process.

Learning will work well if the physical and psychological environment is conducive, conversely if there is pressure, anxiety that is difficult to overcome, and the lack of facilities to vent negative emotions during the quarantine process can have a negative impact on the learning process of IJSO participants. Therefore, guidance and counseling services become an integral part of the quarantine process in order to occupy a strategic position in developing the emotional-social competence of IJSO participants.

Shertzer \& Stone, views guidance as a process of helping and individual to understand himself and his word'. According to Kartadinata "guidance is defined as the process of assistance to individuals in achieving optimum levels of self-development". The guidance service function as a preventive measure in this research is focused on developing emotional- social competence. America School Counselor Association (ASCA) suggests that counseling is a face-to-face relationship that is confidential, full of acceptance and giving opportunities from the counselor to the counselee, the counselor uses his knowledge and skills to help the counselee overcome his problems. The function of counseling services as a curative effort in solving problems related to emotionalsocial competence.

It is important for IJSO participants to obtain guidance and counseling services to achieve personal character by facilitating or helping students get out of problems that can hamper their development both physically and psychologically in the personal, social, academic and career fields. One of the most difficult developmental tasks for adolescents is related to social adjustment [9]. As mentioned in the independent competency standard for students [10], one of the tasks of development is the maturity of peer relations.

\section{METHOD}

The research method uses qualitative research with a phenomenological model. The phenomenological model is used to express the meaning of each phenomenon that occurs around IJSO participants. Hanurawan explains the phenomenological model is a qualitative study that explores in detail a person's personal life experience with the results of a description of how a person gives meaning about phenomena related to the personal world and its solutions. This study aims to find the meaning of emotional-social competence in IJSO participants.

The research subjects were carried out through approaches to groups that had characteristics in accordance with the research topic, personal contacts. The subjects of the study were the 2014-2018 IJSO participants.

Data collection is done by using interviews and observations. Through interviews, researchers try to reduce the many statements made by research participants on a topic to the main propositions or prominent as research. Meanwhile, through observation, researchers make intuitive conclusions obtained by researchers when and after observing the reactions that appear to participants when interacting with topics or phenomena. The data analysis technique used is the phenomenological analysis technique. Significant statements can be found in words, sentences, or several sentences in order to obtain a special meaning about a phenomenon. Johnson \& Christensen explains that significant statements can be found in words, sentences, or phenomena.

\section{RESULT AND DISCUSSION}

Field findings through interviews and observations conducted during the IJSO activities are used to describe emotional-social competencies in dealing with problems or challenges that must be faced by IJSO participants as an impact of self-adjustment to the ability possessed (intelligence above average) during quarantine process.

Based on observations and interviews with IJSO quarantine participants related to the emotional condition of students and social conditions when they have to mingle and are required to be able to cooperate with other participants. Emotional competence that students must have in the aspect of self- awareness is the ability of individuals to build emotional awareness that has an impact on work. Emotional awareness is recognizing the emotion that is felt.

Based on observations and opportunities given to participants to express their feelings and needs, there are only two participants who express clearly their feelings and needs to be able to regulate themselves. While there are also participants who tend to be indifferent to the behavior of friends who are less pleasant when hanging out, but show displeasure when in teamwork cannot work together, such as "Can you not work according to our agreement?" Or "I don't want a group with him sis, because he is selfish".

The self-management aspects shown in the sub aspects are the ability to control self- emotion, achievement orientation, positive thinking, selfadjustment. Participants found it difficult to control emotions during pressures and demands through tests and parental demands, this condition was reported by six participants. A statement that is often made by IJSO participants in this condition is "I don't want to work in groups if he behaves like that". Characteristics of adolescents include trying to defy the rules given by parents. Two of the six participants showed resistance from the rules given by their parents, such as: reading story books, eating food that was not allowed by parents.

This condition according to Yusuf is influenced by a flood of growth hormones in the sexual organs, causing new feelings that have not been experienced before. In early adolescence (students in junior high school), their emotional development shows a very sensitive and reactive (critical) nature towards various social events or situations.

Positive thinking possessed by participants is more faced by participants who feel inferior conditions. Problems or challenges that made the participants reason to feel inferior were bronze medalists while other friends got silver and gold medals. This was seen in a number of participants who seemed unenthusiastic when attending quarantine and complained about the statement "why was I chosen? Even though I just got a bronze ". According to 
Parrot [13] states that sometimes teenagers make statements with minimal facts in reality such as "I'm not smart"; "I'm not attractive". The statement about self that is maintained will hire adolescents into a condition of majority. The process of positive thinking in quarantine settings in achieving goals influences the participant's achievement orientation.

The competence of students in adjusting quickly is demanded in the quarantine process, the challenges faced include when they have to adjust to roommates who come from different regions and when they have to be ready to be paired in practicum groups that are continually adjusted so that changes in group members occur very frequently (group changes occur four to five times). Changing roommates and teammates sometimes becomes a participant's complaint like "I don't want to share a room with him sis, because it's dirty" or "I don't want a group with him sis, because it's not from the same district".

In addition, the sub-aspect of competency that must be possessed by participants is managing emotions, reportedly there are participants who cry hysterically, due to lack of ability to manage emotions when failing to enter the advanced selection stage in quarantine. Information obtained, participants felt they should be able and can enter the next stage. Unrealistic expectations will also develop low self-esteem. Bruce Narramore states that the three common expectations as sources of problems in the process of self-acceptance are 1) I must be able to meet the expectations of others towards me, so that I can be accepted and loved; whenever I fail in achieving my goals, I deserve to be punished, and 3) I must rule the world. Every point of those expectations is irrational and can damage self-esteem.

In addition to the competencies that must be possessed to be intrapersonal, other competencies that demand social competencies include: (1) social awareness shown in the ability to empathize, and organizational awareness (the ability to read the group's emotional conditions and understand the power of relationships, identify networks and group dynamics); and (2) management of the relationships shown in their ability to influence, conflict management, inspirational leaders, and teamwork.

The aspect of social awareness, in the sub- aspect of empathy, is faced when participants are in a background of competence and an atmosphere of competition is built so that they are not excluded from quarantine, the condition of participants who do not want to understand the difficulties of other participants is shown when they do not want to share information or knowledge they have, in one this side of the condition became boomerang because participants were required to develop dynamic groups.

In addition, challenges in developing organizational awareness were more likely to be faced at the beginning of the quarantine process, while participants were building their own group dynamics. This was seen when the participants were given assignments by the lecturer, some participants showed no desire to share information such as trying to avoid saying "I'm not done yet" or "wait a minute, I want to do this part first". In essence the process of building a dynamic group will go through the stages of forming (storming), storming, norming, performing. However, the process of dynamics within the group through each phase will be necessary and inevitable so that the group can grow, face challenges, overcome problems, find solutions, plan work, and deliver results.

In the aspect of relationship management, the challenges faced are especially when working in groups. Each participant is required to give each other room to each group of friends to develop each task they carry, trust, share assignments effectively, and encourage each other is a challenge for participants to be able to influence, mentor, manage conflict, become an inspirational leader, and show dynamic teamwork.

If participants feel that they are compatible with the group formed, they will say "Sis, please, the team should not be changed anymore" or if the participants do not agree with the team formed, the statement is "Sis, it still doesn't fix the formation of the group?". Adolescent social competence in practice influences one another. The vital role of emotions for individuals is emotional information that involves understanding self-emotions and group emotions will help teens to motivate and direct attention, and facilitate group relationships.

Basically, the high intellectual ability possessed by IJSO participants, helps them to develop ethically sensitive attitudes and better moral development, besides that in some cases teenagers are also identified as having social and emotional development more mature. Appropriate handling in dealing with gifted adolescents has an impact on the perception of gifted adolescents on their environment, because after all according to LJ. Coleman \& Cross argues that perceptions and forms of behavior of people around to students about their abilities have a real effect on their social interactions.

As an effort to facilitate the development of IJSO participants in fulfilling development tasks so that they develop naturally in various life settings. Guidance and counseling services in group settings can be provided as direct and indirect interventions. Direct intervention can be given in individual settings or group settings. Service components that can be provided are basic services and responsive services.

While the form of indirect intervention services will be more focused on efforts to develop a development environment (in reach-out reach) in the interests of facilitating the development of IJSO participants, this activity will involve many parties in it. The parties involved were IJSO participants, the Ministry of Education and Culture as the organizer of the quarantine process, parents and schools as a support system for the participants.

\section{CONCLUSION}

The social emotional competence of IJSO participants shows that they have not been able to consciously recognize emotions, manage emotions, feel inferior, have empathy and be able to work with anyone. Important guidance and counseling services are provided to IJSO participants as a facilitator in developing superior characteristics. In addition, with the presence of guidance and counseling services IJSO participants are expected to be able to resolve conflicts in the quarantine process. 


\section{REFERENCES}

[1] Zeidener \& Zinovic, I. (2013). Research On Personality and Affetive Dispositions of Gifted Children: The Israel Scane. Gifted and Talented International XXVIII (1), 35-49.

[2] Boyatzis \& Goleman. (2011). Emotional and Social Competency Inventory. USA: haygroup Communication in Groups and Teams. Bloomington: Universe.

[3] Hurlock, E. (1980). Psikologi Perkembangan. Jakarta: Erlangga.

[4] Fuhrmann B.S. (1990). Adolescence, adolescent. London: Foresman and Company

[5] Daniel Goleman. (1995). Emotional Intelligence. Jakarta: Gramedia Utama.

[6] Shertzer, B. S., \& Stone, S. C. (1981). Fundamentals of guidance. Boston, MA: Houghton Mifflin Company.

[7] Kartadinata, Sunaryo. (2003). Arah Tantangan Bimbingan dan Konseling Perkembangan. Pendidikan dan Konseling di Era Global. Bandung: Rizqi Press.

[8] Suherman, Uman AS. (2007). Manajemen Bimbingan dan Konseling. Bekasi : Madani Production

[9] Hurlock E. B. (2004). Psikologi Perkembangan: Suatu Pendekatan Sepanjang Rentang Kehidupan. Jakarta: Erlangga.
[10] Dirjen PMPTK. (2007). Rambu-rambu penyepenggaraan bimbingan dan konseling dalam jalur pendidikan formal Jakarta: Depdiknas.

[11] Hanurawan, F. 2016. Metode Penelitian Kualitatif untuk Ilmu Psikologi. Jakarta:

[12] PT Raja Grafindo Persada

[13] Yusuf, S. (2009). Program Bimbingan dan Konseling Di Sekolah. Bandung: Rizqi Press.

[14] Parrot, L. (2000). Helping Your Struggling Teenager. Michigan: Zondervan Publishing House.

[15] Egolf, D \& Chester, S. (2013). Forming Storming Norming Performing Successful

[16] Lewis \& Haviland-Jones. (2000). Handbook of Emotions. New York : Guilford Publications.

[17] Schutte, I \& Tirri, K. (2014). The relationship between ethical sensitivity, high ability and gender in higher education students. Gifted and Talented International XXIX(1), 39-48

[18] Gallagher, S. \& Smith, S. (2011). Teachers perceptions of the socioemotional development of intellectually gifted primary aged student and their attitudes towards ability grouping and acceleration. Gifted and Talented International XXVI(1), 11-23.

[19] Coleman, L \& Cross, T. (1988). Is being gifted a social handicap. Journal for the Education of the Gifted, XI(4). 4156. 